\title{
Can isoprenoids in leaves and roots of plants serve as biomarkers for past vegetation changes? A case study from the Ecuadorian Andes
}

\author{
Boris Jansen · Klaas G. J. Nierop · Femke H. Tonneijck • \\ Frans W. M. van der Wielen · Jacobus M. Verstraten
}

Received: 18 October 2006 / Accepted: 15 December 2006 / Published online: 17 January 2007

(C) Springer Science+Business Media B.V. 2007

\begin{abstract}
Large-scale clear-cutting and burning caused the altitude of the natural upper forest line (UFL) in the Northern Ecuadorian Andes to decline to the point that its 'natural' position is now uncertain. To obtain a detailed reconstruction of the dynamics of the UFL over the last few thousand years, traditional proxies alone do not suffice. For instance, pollen analysis suffers from a low altitudinal resolution due to the large windblown component. In an attempt to find new, additional proxies to study past UFL dynamics in the Ecuadorian Andes, we investigated the occurrence of isoprenoids (diterpenes, phytosterols and pentacyclic triterpenoids) in the roots and leaves of 19 plant species responsible for the dominant biomass input in soil and peat records along altitudinal transects covering approximately $500 \mathrm{~m}$ above and below the current UFL in two locations in the Northern Ecuadorian Andes. Isoprenoids can serve as biomarker if they are uniquely present in a relevant plant species and preserved well enough in chronological order in
\end{abstract}

\footnotetext{
B. Jansen $(\bowtie)$ · K. G. J. Nierop · F. H. Tonneijck · F. W. M. van der Wielen - J. M. Verstraten Institute for Biodiversity and Ecosystem Dynamics Earth Surface Processes and Materials (IBED-ESPM), Universiteit van Amsterdam, Nieuwe Achtergracht 166, NL1018 WV Amsterdam, The Netherlands e-mail: b.jansen@uva.nl
}

suitable records. Such biomarkers could help establish past vegetation dynamics including the UFL position. For an isoprenoid to be a biomarker in soils normally it must be absent from the roots of a plant species as roots do not enter soils in chronological order. For peat deposits this criteria only needs to be met for the peat species themselves as only roots from peat species will be present. Two diterpenes, four phytosterols and six pentacyclic triterpenoids met the criteria for biomarker in peat records. Of these, one diterpene, two phytosterols and three pentacyclic triterpenoids also met the criteria for biomarker in soils. Samples from a soil under forest, a soil under the adjacent páramo and a nearby peat deposit, ${ }^{14} \mathrm{C}$ dated at approximately 1500 cal. AD and $200 \mathrm{cal}$. AD, were tested for the presence of isoprenoids that meet the criteria for biomarker. Such isoprenoids were only found in the peat bog samples. However, we found that changes of number and concentrations of isoprenoids with depth might provide additional information related to past vegetation changes. In conclusion, isoprenoids show potential for use in a multiproxy approach to reconstruct past UFL locations in the Northern Ecuadorian Andes and other ecosystems with similar vegetation and soils.

Keywords Andic soil - Biomarkers ·

Diterpenes · Peat - Pentacyclic triterpenoids .

Phytosterols 


\section{Introduction}

Montane cloud forests and Montane tropical alpine grasslands (páramo) compose the fragile ecosystems that nowadays are encountered only in selected places in the higher parts of the Ecuadorian Andes. However, cloud forests are believed to have once covered much larger areas, and human interference through clear-cutting and burning is held responsible for a significant reduction of cloud forest coverage and a depression of the upper forest line (UFL) in the entire Ecuadorian Andes (e.g. Dodson and Gentry 1991; Laegaard 1992). Publications like the one by Laegaard (1992) have been used to justify replanting efforts above the current UFL as a reconstruction of natural forest destroyed by humans. However, the past 'natural' locations of the UFL in the Ecuadorian Andes are subject of scientific debate (e.g. Wille et al. 2002). A lower natural UFL than indicated by Laegaard (1992) would mean that replanting efforts may not be reconstructing past forest vegetation, but destroying a natural páramo ecosystem. Therefore, to enable sustainable and ecological management of the current Montane ecosystems in Northern Ecuador and possible reconstruction of degraded areas, the question what the 'natural' location of the UFL would have been in the absence of human disturbance must be addressed.

In their recent attempt to reconstruct the natural UFL position in the Ecuadorian Andes, Wille et al. (2002) reconstructed shifts of the UFL during the last 700 years through a combination of analysis of the current vegetation and fossil pollen analysis from peat cores. While important insights into past UFL positions were born from their study, Wille et al. (2002) also recognized the limitations of the proxies applied. For instance, the spatial resolution of pollen analyses is limited by the dispersal of pollen by wind prior to deposition, whereas a UFL reconstruction by vegetation analysis is only possible if sufficient traces of the original forest remain, which in most areas in the Ecuadorian Andes is not the case.

Analogous to the above-mentioned study, we are currently attempting a reconstruction of the vegetation history in the Northern Ecuadorian Andes covering a period of time predating the onset of large-scale human interference. To obtain as detailed as possible a reconstruction of past UFL positions we need to overcome the limitations of pollen and vegetation analysis as recognized by Wille et al. (2002). Therefore, we are investigating the possibility of applying new additional proxies in conjunction with traditional pollen and vegetation analysis. Biomarkers constitute one such proxy that may offer opportunities for reconstructing past vegetation compositions including the historic UFL position. Biomarkers are defined as organic chemical components, or groups of components, exclusive to relevant plant species and preserved in chronological order in suitable records such as peat deposits, sediments or soils. In a previous study we successfully tested the occurrence of plantspecific combinations of straight-chain lipids in plants responsible for the dominant biomass input into soil and peat records in our research area, and tested their preservation (Jansen et al. 2006a). However, in the case of straight-chain lipids, the distinction of plant species is based on the occurrence of unique combinations of otherwise ubiquitous compounds with different carbon chain-lengths. As a consequence, unraveling such unique combinations from the mixed straightchain lipid signal found in soil, peat or sediment records that contain the combined input of many plants, is a challenge (Jansen et al. 2006a).

To help overcome the limitations of straightchain lipid biomarkers it would be very helpful to have a second set of biomarkers at our disposal, based on unique individual components instead of unique combinations of otherwise common compounds. Isoprenoids may constitute such a class of components. Like straight-chain lipids, isoprenoids and in particular diterpenes, phytosterols and pentacyclic triterpenoids, have been considered as biomarkers in the past and have in some cases been linked to specific plants or groups of plants (e.g. Chaffee et al. 1986; Ohsaki et al. 1999; Simoneit 1986; Volkman 2005). Diterpenes in paleoecological records mainly originate from higher plant waxes and resins, and consist of amongst others the abietanes, pimaranes, kauranes, podocarpanes and labdanes as well as their derived acids, alcohols, etc. (Simoneit 1986). Phytosterols occur in all higher plants and derive 
from the common precursor cycloartenol, as opposed to fungal and animal sterols that derive from lanosterol (De Leeuw and Baas 1986). Common plant-derived pentacyclic triterpenoids include the friedelanes, taraxeranes and ursanes as well as their derived alcohols, acids, etc. (Killops and Frewin 1994; Simoneit 1986). For all three compound classes, it is their distinct, predominantly plant-derived origin that makes them potential biomarkers (Killops and Frewin 1994; Ohsaki et al. 1999; Volkman 2005). In addition, potential persistence of isoprenoids in paleological records is indicated by several authors (e.g. Jaffe et al. 1996; Simoneit 1986). The component classes under consideration are all lipids (Dinel et al. 1990), which according to the most common definition are organic components soluble in organic solvents but insoluble in water (Bull et al. 2000b). As a consequence, vertical mobility in the form of leaching upon dissolution will be limited. At the same time in soil records, leaching in the form of dispersed colloids is expected to be limited as well, since clay translocation is normally not considered a dominant process in Andosols, due to the difficult dispersion of amorphous clay minerals (Shoji et al. 1993).

However, there are potentially serious drawbacks to the application of isoprenoids as biomarkers as well. A first problem is that the number of databases of the occurrence of specific isoprenoids in different plants is extremely limited. This is illustrated by Volkman (2005) who, in his recent review of the use of triterpenoids as biomarkers, indicated that the absence of suitable reference databases is severely hindering their application in paleoecological reconstructions. The lack of suitable databases makes it impossible to assess the uniqueness of specific isoprenoids for specific plants beforehand. A second concern is that in spite of the potential persistence indicated in literature, alteration, microbial degradation and/or inextractable immobilization on the solid matrix, e.g. as insoluble esters, may be a concern especially in soils (Bull et al. 2000a, b; Otto et al. 2005; Otto and Simpson 2005; Van Bergen et al. 1997).

The purpose of the present study was to assess the applicability of isoprenoid biomarkers as a proxy in reconstructing the upper forest line in the Northern Ecuadorian Andes. Considering the potential drawbacks mentioned, the goal was specifically to: (i) construct a database of diterpenes, phytosterols and pentacyclic triterpenoids present in the plant species responsible for the dominant biomass input into paleoecological records in our study area, (ii) identify possible biomarkers from the compounds found, (iii) perform a preliminary assessment of the occurrence and preservation of any identified isoprenoid biomarkers in selected paleological records in the area.

\section{Materials and methods}

\section{Description of the study sites}

Our study area consists of (i) the Guandera Biological Station and (ii) the combined area of El Angel Ecological Reserve and Los Encinos Biological Station in El Carchi province, Ecuador. Both sites are located in an area identified by Myers (1988) as part of the "tropical Andes hotspots", characterized by exceptionally high levels of plant endemism, but at present-day also by serious levels of habitat loss.

Guandera Biological Station is a relatively undisturbed site located approximately $11 \mathrm{~km}$ from the small town of San Gabriel in the Ecuadorian Eastern Cordillera at GPS coordi-

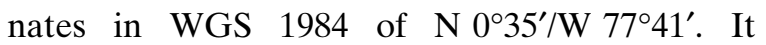
protects approximately 1,000 ha of high altitude páramo grassland as well as areas of relatively undisturbed Montane cloud forest. Most of this Andean forest is located between 3,300 m.a.s.l and 3,640 m.a.s.l and consists of Upper Montane Rainforest (UMRF) at lower altitudes, changing into Sub-Alpine Rainforest (SARF) found as dwarf forest at higher altitudes along the current UFL as well as in isolated patches above the UFL. Above 3,640 m.a.s.l grass páramo (PAR) dominates the landscape but some SARF patches occur up to 3,700 m.a.s.l. The highest altitude in the study area is approximately 4,100 m.a.s.l.

The combined El Angel Ecological Reserve and Los Encinos Biological Station on the other hand form a relatively disturbed site located in 
the Ecuadorian Western Cordillera on the southern slopes of Volcano Chiles. General GPS coordinates in WGS 1984 are N 0³9'/W 7752'. For centuries this area was subject to intensive anthropogenic disturbance including clear-cutting, burning and cattle farming but is now protected by conservations laws. The only forest remnants in this location consist of isolated forest fragments between approximately 3,450 m.a.s.l. and 3,700 m.a.s.l. Fragments of both UMRF and SARF are present. In between the forest fragments and integrally above an altitude of 3,700 m.a.s.l., the area is dominated by grass páramo, while the highest altitude in this study area is approximately 4,100 m.a.s.l.

The Guandera study area in the Eastern Cordillera receives almost double the annual precipitation of the El Angel/Los Encinos study areas in the Western Cordillera (annual means, respectively, 1,900 and $1,000 \mathrm{~mm}$ ), but mean annual temperatures are similar (from $10^{\circ} \mathrm{C}$ at 3,400 m.a.s.l. to $4^{\circ} \mathrm{C}$ at 4,000 m.a.s.l.). The geobotanical background of both study areas is provided by Ramsay and Oxley (2001).

In Guandera, soils change along an altitudinal transect from Histosols with andic properties at sites currently covered by forest, via a Cambisol with andic properties in the forest patch above the UFL, to Andosols at sites currently covered by páramo vegetation. One should note that it is the exceptionally thick organic horizons that prevented the soils under forest to classify as Andosols. In all other aspects the soils met the criteria for Andosols. In El Angel/Los Encinos all studied soils, including one underneath a forest patch, classified as Andosols.

Paleological records present in the study sites

Possible biomarker records of isoprenoids in the research area are peat deposits and soils. In Guandera one peat deposit was identified in the current grass páramo at 3,869 m. In El Angel/Los Encinos two peat deposits were encountered; one at $3,418 \mathrm{~m}$ and one at $3,740 \mathrm{~m}$. While peat deposits constitute traditional paleological records, the use of soils as such is less straightforward. However, volcanic ash soils as present in our study have been used successfully by several authors in the past due to the good chronostratification and preservation of organic matter (e.g. Moore et al. 1991; Salomons 1986).

Important insights into the chronostratigraphy of the soils in our study area were obtained from a previous study of their age-depth relationship, which was found to show a very clear linear increase of age with depth in all soils $\left(r^{2}=0.87\right.$ when all soils were combined) and lacking age inversions (Tonneijck et al. 2006). The linear increase of age with depth that was observed, shows that bioturbation did not homogenize SOM at the scale of the applied vertical sampling distances. These were on average 40 and $15 \mathrm{~cm}$ in the two soil profiles that were sampled for a preliminary assessment of the presence of isoprenoids as part of the present study (see "preliminary assessment of isoprenoids in paleorecords") (Tonneijck et al. 2006). Furthermore, Andosols generally show strong resistance to water erosion due to rapid rain infiltration and high aggregate resistance to dispersion, thereby limiting the risk of erosion disturbing the chronostratigraphy (Shoji et al. 1993).

The soils in both study areas generally possess high organic carbon contents $(8.0-25 \%$ in the upper mineral horizons), acidic $\mathrm{pH}\left(\mathrm{pH}_{0.01 \mathrm{MCaCl}_{2}}\right.$ 3.2-4.2) and high moisture contents. An acidic $\mathrm{pH}$ and high moisture content are regarded as favorable for the preservation of lipids, since they inhibit microbial activity (Stevenson 1994). In addition, all soils contained some allophane (on average $3.0 \pm 2.6 \%$ ) and abundant organic Aland Fe-complexes as well as Al- and Fe-hydroxides, all of which may further stabilize organic matter, although their exact contribution to organic matter stabilization is subject of debate (Nierop et al. 2005). All together, we conclude that the chronostratigraphy of SOM in the soils of our study area as well as the potential for preservation appear to be suitable for paleoecological research such as reconstruction of the natural position of the UFL.

To describe and classify the soils present in the study area, pits of approximately $1 \mathrm{~m}^{2}$ surface area and a depth of 1.5-2 $\mathrm{m}$ depending on the soil profile were excavated, and soil profiles described according to the FAO guidelines and classified according to the FAO World Reference Base for 
soil resources (FAO 2006). During the assessment, care was taken to search for signs of creep or solifluction. Any sites showing such indications were avoided. In total 15 soils were described, 10 in Guandera and five in El Angel. Generally, the horizon sequence in both study areas can be summarized as $\mathrm{Ah} 1-\mathrm{Ah} 2 / \mathrm{Bw}-2 \mathrm{Ahb}-$ (2Bwsb) $-2 / 3 \mathrm{BCb}$, common for volcanic ash soils (Shoji et al. 1993). As mentioned previously, the forest profiles contained organic horizons overlying the mineral horizons, ranging from $75 \mathrm{~cm}$ to $100 \mathrm{~cm}$ thick at sites currently covered by forest to $5-35 \mathrm{~cm}$ at the UFL or within forest patches. Under páramo vegetation organic horizons were virtually non-existent, since litter was concentrated within the grass tussocks rather than on the ground surface. Generally, all soils showed a multisequum, i.e. a sequence of buried soil profiles or paleosols originating from sequential tephra deposits separated by time. For a detailed description of several individual soils characterized along the altitudinal transects in both study areas we refer to Tonneijck et al. (2006).

\section{Collection of leaves and roots}

In the study areas of Guandera and El Angel/Los Encinos, the plant species responsible for the dominant biomass input into soil and peat depos- its were identified at key locations relevant for the UFL position: (i) the UMRF, (ii) the SARF, (iii) the grass páramo and (iv) the peat bogs. A list of the species collected at the different locations is provided in Tables 1 and 2. Identifications were carried out at the Herbarium of the Pontificia Universidad Católica del Ecuador (PUCE) in Quito, Ecuador by M. Moscol, M.Sc., under supervision of Prof. dr. A.M. Cleef, both of the Universiteit van Amsterdam, The Netherlands. One species of the prominent forest genus Tillandsia could not be identified and has therefore been denoted Tillandsia sp.2. Voucher specimens have been deposited at the Herbarium of the PUCE in Quito, Ecuador.

Contrary to for instance lake sediments, in soils and peat bogs roots may be responsible for a significant part of the plant biomass input, albeit only of the peat plants themselves in the latter (e.g. Nierop and Verstraten 2004). Therefore, separate samples of living roots and leaves were taken from each of the species under consideration to investigate their isoprenoid contents. Roots were sampled by excavating enough soil surrounding a living plant to expose a sufficient part of its roots, and cutting off some root material. An exception is formed by Oreobolus goeppingeri and Oreobolus obtusangulus for which separate collection of roots and leaves

Table 1 Dominant biomass forming species in the Guandera Biological Station in the Eastern Cordillera, that were sampled for analysis of their potential isoprenoid biomarker composition in roots and leaves

\begin{tabular}{|c|c|c|c|}
\hline Biotope & Growth form & Family & Genus, species and identification \\
\hline $\begin{array}{l}\text { Upper Montane Rain Forest } \\
\text { (UMRF) }\end{array}$ & $\begin{array}{l}\text { Evergreen tree }^{\mathrm{a}} \\
\text { Epyphyte } \\
\text { Fern }\end{array}$ & $\begin{array}{l}\text { Clusiaceae } \\
\text { Bromeliaceae } \\
\text { Blechnaceae }\end{array}$ & $\begin{array}{l}\text { Clusia flaviflora Engl. } \\
\text { Tilandsia } \text { sp. } 2 \\
\text { Blechnum schomburgkii (Klotzch) C.Chr. }\end{array}$ \\
\hline $\begin{array}{l}\text { Sub-Alpine Rain Forest (SARF) } \\
\text { and extrazonal forest patches }\end{array}$ & $\begin{array}{l}\text { Shrub } \\
\text { Fern } \\
\text { Evergreen tree }^{\mathrm{a}} \\
\text { Evergreen tree }^{\mathrm{a}} \\
\text { Bamboo }\end{array}$ & $\begin{array}{l}\text { Loranthaceae } \\
\text { Blechnaceae } \\
\text { Melastomataceae } \\
\text { Cunoniaceae } \\
\text { Poaceae }\end{array}$ & $\begin{array}{l}\text { Gaiadendron punctatum (Ruiz \& Pav.) G. Don } \\
\text { Blechnum schomburgkii (Klotzsch) C. Chr. } \\
\text { Miconia tinifolia Naudin } \\
\text { Weinmannia cochensis Hieron. } \\
\text { Neurolepis aristata (Munro)Hitchc. }\end{array}$ \\
\hline Grass páramo & $\begin{array}{l}\text { Grass } \\
\text { Sedge } \\
\text { Stem rosette } \\
\text { Sedge }\end{array}$ & $\begin{array}{l}\text { Poaceae } \\
\text { Cyperaceae } \\
\text { Asteraceae } \\
\text { Cyperaceae }\end{array}$ & $\begin{array}{l}\text { Calamagrostis effusa (Kunth) Steud. } \\
\text { Rhynchospora ruiziana Boeck. } \\
\text { Espeletia pycnophylla Cuatrec. } \\
\text { Oreobolus goeppingeri Suess. }\end{array}$ \\
\hline
\end{tabular}

Lower peat bog in/close to UMRF Not encountered at the time of collection

Upper peat bog in grass páramo Sedge Cyperaceae Oreobolus cf. obtusangulus Gaudich.

Species present in multiple biotopes were only sampled in one biotope

a Trees never exceeded $10 \mathrm{~m}$ in height 
Table 2 Dominant biomass forming species in the El Angel Ecological Reserve and Los Encinos Biological Station in the Western Cordillera, that were sampled for analysis of their potential isoprenoid biomarker composition in roots and leaves

\begin{tabular}{|c|c|c|c|}
\hline Biotope & Growth form & Family & Genus, species and identification \\
\hline \multirow{4}{*}{$\begin{array}{l}\text { Upper Montane Rain Forest } \\
\text { (UMRF) }\end{array}$} & Evergreen tree ${ }^{a}$ & Melastomataceae & Miconia tinifolia Naudin \\
\hline & Shrub & Chloranthaceae & Hedyosmum cumbalense H. Karst. \\
\hline & Evergreen tree $^{\mathrm{a}}$ & Elaeocarpaceae & Vallea stipularis L.f. \\
\hline & Shrub & Ericaceae & Macleania rupestris (Kunth) A.C. Sm. \\
\hline \multirow{3}{*}{$\begin{array}{l}\text { Sub-Alpine Rain Forest (SARF) } \\
\text { and extrazonal forest patches }\end{array}$} & Evergreen tree ${ }^{a}$ & Asteraceae & Gynoxys buxifolia (Kunth) Cass. \\
\hline & Evergreen tree ${ }^{a}$ & Melastomataceae & Miconia tinifolia Naudin \\
\hline & Evergreen tree $^{a}$ & Cunoniaceae & Weinmannia cochensis Hieron. \\
\hline \multirow[t]{4}{*}{ Grass páramo } & Grass & Poaceae & Calamagrostis effusa (Kunth) Steud. \\
\hline & Sedge & Cyperaceae & Rhynchospora ruiziana Boeck. \\
\hline & Stem rosette & Asteraceae & Espeletia pycnophylla Cuatrec. \\
\hline & Sedge & Cyperaceae & Oreobolus goeppingeri Suess. \\
\hline \multirow[t]{3}{*}{ Lower peat bog in/close to UMRF } & Rush & Juncaceae & Juncus balticus ssp. andicola (Hook.) Snogerup \\
\hline & Herb & Plantaginaceae & Plantago australis Lam. \\
\hline & Herb & Rosaceae & Lachemilla andina (L.M. Perry) Rothm. \\
\hline Upper peat bog in grass páramo & Sedge & Cyperaceae & Oreobolus cf. obtusangulus Gaudich. \\
\hline
\end{tabular}

Species present in multiple biotopes were only sampled in one biotope

a Trees never exceeded $10 \mathrm{~m}$ in height

proved not feasible because both plants are very compact, with short roots and small leaves that are difficult to distinguish from the roots. Due to plant morphology, material of these two species is expected to enter soil and/or peat records in a 1:1 leaf-to-root ratio.

We always sampled material from several specimens of the same species at random within the respective biotope of occurrence and collected leaves and roots of different degrees of maturity and size. The isoprenoid signal preserved in the soil and peat records is a mixed signal composed of many different specimens from the same species. As such it is much more important to obtain the average isoprenoid signal from the plant species in questions than to know the inter-specimen variance in the signal. This led to the decision to mix the leaf material from the various specimens of the same species and mix the root material from the various specimens of the same species to obtain the average isoprenoid signal in leaves and roots, while always keeping leaves and roots separately.

All root and leave samples were collected and transported in aluminum foil to avoid handcontact and dry $\mathrm{MgSO}_{4}$ was added to limit fungal growth during transport. All samples were freezedried, grinded, sieved over $2 \mathrm{~mm}$, homogenized and stored at $2^{\circ} \mathrm{C}$ awaiting subsequent extraction and analysis.

Criteria for using isoprenoids as biomarker in soils and peat deposits

For an isoprenoid to qualify as biomarker it must be exclusively present in one of the plant species under study and be preserved in soils or peat deposits in chronological order. To enable the latter, the manner of deposition of the plant material containing the potential biomarker must be taken into account. Leaves enter soil records in a chronological order and the isoprenoids released upon the decomposition of leaves in the soil will remain in a chronological order since they are expected to be immobile in the soils in our study area as pointed out earlier. Roots on the other hand will grow vertically into a soil record, potentially depositing their isoprenoids in a non-chronological order upon decay. In contrast, in peat bogs, the disturbance of the record by non-chronological input of isoprenoids from roots is limited, as only roots of the peat plants are expected to be present. Other plants will be predominantly represented by wind-blown leaf material from the surrounding local vegetation at close distance. As a 
consequence, in soils the input of roots of all plants of interest must be taken into account, while in peat records the input of roots from all but the peat species themselves will be absent and can consequently be ignored.

Therefore, an isoprenoid qualifies as a biomarker in soils if it is present exclusively in the leaves of a single plant species of interest but absent from its roots. In peat deposits, with the exception of the peat species themselves, an isoprenoid also qualifies as a biomarker if it is present in the roots as well as the leaves of a plant species of interest since only roots of peat species will be present in peat records. An exception to these rules are formed by the two Oreobolus species for which roots and leaves were not sampled separately due to their compactness. It is the same compactness that strongly limits vertical penetration of their roots into soil and/or peat records and as such any isoprenoids unique to either of the Oreobolus species were considered biomarkers for soil as well as peat even though their distribution over leaves and roots was unknown.

Preliminary assessment of isoprenoids in paleorecords

From the majority of the soil pits that were used to describe and classify the soils in the study area as described previously, undisturbed soil monoliths were collected for future use as paleological records of amongst others straight-chain lipid biomarkers, pollen and possibly isoprenoids. The monoliths were taken with one or more metal gutters with a dimension of $75 \times 5 \times 4 \mathrm{~cm}^{3}$ that were vertically inserted into the profile exposed in the soil pit. From the various monoliths collected, two were selected for a preliminary assessment of the presence of isoprenoid biomarkers and their potential for reconstructing the historic UFL as part of the present study.

The two monoliths in question were both taken from the Guandera study area. Specifically, one soil monolith was taken from a pit dug in a patch of SARF above the current UFL and the other from a pit dug in the páramo grassland adjacent to the forest patch. In addition, one undisturbed peat core from the Guandera study area was selected. A detailed description of the location of the two monoliths and the peat core is given in Table 3. From each of the two monoliths and the single peat core, two sub-samples at different depths were taken. The sub-samples were taken from the intact monoliths by using a small corkauger with a diameter of $1.0 \mathrm{~cm}$. The sub-samples from the peat core were taken by cutting off a slice of core with a thickness of $1.0 \mathrm{~cm}$ as using the cork-auger proved impossible.

From our previous study of the age-depth relationship in soils and peat deposits in the study area (Tonneijck et al. 2006), radiocarbon dates obtained from the same soil monoliths and peat core selected for the present study were available. Based on the available radiocarbon dates, subsamples for the present study were taken at depths corresponding to calibrated ${ }^{14} \mathrm{C}$ ages in the vicinity of $1500 \mathrm{AD}$ and $200 \mathrm{AD}$. In the case of the soil monoliths both the upper and lower sample were from the same soil horizon (Ah), thus avoiding changes in organic carbon content between the two samples. The exact depths of the sub-samples as well as the radiocarbon dates are presented in Table 3.

While the first human settlers may have entered the area as early as $3000-4000$ years ago (Brush 1982), the onset of massive human interference is generally thought not to have occurred before the Spanish conquest of Ecuador in the early 1600s. As such the selected samples reflect a time frame predating the onset of massive human interference in the UFL position. The selected soil- and peat-samples were freeze-dried, grinded and homogenized prior to extraction, analysis and signal interpretation following the same procedure as for the plant samples.

Extraction, clean-up and derivatization

All solvents used were of gas chromatographymass spectrometry (GC-MS) grade. Containers that came in contact with samples were carefully cleaned with acetone to avoid contamination with lipids.

Extraction of the lipid fraction, which included the isoprenoids under study, were carried out with a Dionex 200 Accelerated Solvent Extractor (ASE) at a temperature of $75^{\circ} \mathrm{C}$ and a pressure of $17 \times 10^{6} \mathrm{~Pa}$ employing a heating phase of $5 \mathrm{~min}$ 
Table 3 Description of soil and peat samples from the Guandera study site used for isoprenoid extractions

\begin{tabular}{|c|c|c|c|c|c|c|}
\hline $\begin{array}{l}\text { Soil type } \\
\text { (FAO) }\end{array}$ & $\begin{array}{l}\text { Altitude } \\
\text { (m a.s.1.) }\end{array}$ & Description & Coordinates $^{\mathrm{a}}$ & $\begin{array}{l}\text { Sampling } \\
\text { depths }(\mathrm{cm})\end{array}$ & $\begin{array}{l}\text { Mean calibrated }{ }^{14} \mathrm{C} \text { age } \\
\text { of closest radiocarbon } \\
\text { dated samples from } \\
\text { our previous study }\end{array}$ & $\begin{array}{l}\text { International } \\
\text { Laboratory code }\end{array}$ \\
\hline \multirow{2}{*}{$\begin{array}{l}\text { Andic } \\
\text { Cambisol }\end{array}$} & \multirow[t]{2}{*}{$3697 \pm 9$} & SARF & N $0{ }^{\circ} 35^{\prime} 41^{\prime \prime} /$ & $63.0-64.0$ & $1495 *$ cal AD $(59.5-60.0 \mathrm{~cm})$ & GrA 28102 \\
\hline & & $\begin{array}{l}\text { Forest patch in } \\
\text { páramo }\end{array}$ & W $77^{\circ} 41^{\prime} 36^{\prime \prime}$ & $70.0-71.0$ & $171 \mathrm{cal} \mathrm{AD}(74.5-75.0 \mathrm{~cm})$ & GrA 30114 \\
\hline \multirow[t]{2}{*}{ Andosol } & \multirow[t]{2}{*}{$3694 \pm 13$} & \multirow[t]{2}{*}{ Páramo } & N $0^{\circ} 35^{\prime} 41^{\prime \prime} \mid$ & $12.0-13.0$ & $1335 \mathrm{cal}$ AD $(14.5-15.0 \mathrm{~cm})$ & GrA 30138 \\
\hline & & & W $77^{\circ} 41^{\prime} 35^{\prime \prime}$ & $42.0-43.0$ & $80 \mathrm{cal} \mathrm{AD}(49.5-50.0 \mathrm{~cm})$ & GrA 30139 \\
\hline \multirow[t]{2}{*}{ Histosol } & \multirow[t]{2}{*}{3869} & \multirow[t]{2}{*}{ Peat bog } & $\mathrm{N} 0^{\circ} 35^{\prime} 42^{\prime \prime} \mid$ & $70.0-71.0$ & $1550 *$ cal AD $(70.0-71.0 \mathrm{~cm})$ & GrA 30157 \\
\hline & & & W $77^{\circ} 41^{\prime} 14^{\prime \prime}$ & $130.0-131.0$ & 233 cal AD $(130.0-131.0 \mathrm{~cm})$ & GrA 30132 \\
\hline
\end{tabular}

${ }^{a}$ GPS coordinates in WGS 1984, altitudes from altimeter, GPS altitude used for peat bog site

b From (Tonneijck et al. 2006), except for the samples marked with an asterisk that constitute new samples obtained via the procedures described by (Tonneijck et al. 2006)

and a static extraction time of $20 \mathrm{~min}$ (Jansen et al. 2006b). $\mathrm{CH}_{2} \mathrm{Cl}_{2} / \mathrm{MeOH}(93: 7 \mathrm{v} / \mathrm{v})$ was used as the extractant (Jansen et al. 2006b). Upon extraction, we used an extract clean-up procedure analogous to one described by Naafs et al. (2004). First, the $\mathrm{CH}_{2} \mathrm{Cl}_{2} / \mathrm{MeOH}$ phase was rotary evaporated to complete dryness after which the dry extract was re-dissolved in approximately 2-5 ml $\mathrm{CH}_{2} \mathrm{Cl}_{2} / 2$-propanol $(2: 1 \mathrm{v} / \mathrm{v})$. Next, the extract was filtered using a Pasteur pipette packed with defatted cotton wool, $0.5 \mathrm{~cm} \mathrm{MgSO}_{4}(\mathrm{~s})$ as a drying agent and $2 \mathrm{~cm} \mathrm{SiO}_{2}(\mathrm{~s})$ to remove very polar constituents. To the filtered extracts, we added known amounts of an internal standard consisting of $\mathrm{d}_{42}-n-\mathrm{C}_{20}$ alkane, $\mathrm{d}_{41}-n-\mathrm{C}_{20}$ alcohol and $\mathrm{d}_{39}-n-\mathrm{C}_{20}$ fatty acid, after which we dried the extracts under $\mathrm{N}_{2}(\mathrm{~g})$. The addition of the internal standard at this point means that effects of the sample treatment procedure prior to it, while expected to be small, are not compensated for. To the dried extracts we added $100 \mu$ l of cyclohexane as well as $50 \mu \mathrm{l}$ of BSTFA ( $N, O$-bis(trimethylsilyl) trifluoroacetamide) containing $1 \%$ TMCS (trimethylchlorosilane). Subsequently, the mixture was heated for $1 \mathrm{~h}$ at $70^{\circ} \mathrm{C}$ to derivatize all free hydroxyl and carboxylic-acid groups to their corresponding trimethylsilyl (TMS) ethers and esters. After derivatization, the solutions were dried once more under $\mathrm{N}_{2}$ to remove the excess BSTFA, and subsequently re-dissolved in 200$1000 \mu \mathrm{l}$ of cyclohexane depending on the extraction yields.

\section{GC-MS analyses}

GC-MS analyses of the derivatized samples were performed on a ThermoQuest Trace GC 2000 gas chromatograph connected to a Finnigan Trace MS quadrupole mass spectrometer. Separation took place by on-column injection of $1.0 \mu \mathrm{l}$ on a $30 \mathrm{~m}$ Rtx-5Sil MS wall coated open tubular (WCOT) column (Restek) with an internal diameter of $0.25 \mathrm{~mm}$ and film thickness of $0.1 \mu \mathrm{m}$, preceded by a 2 m Siltek Guard column (Restek) with an internal diameter of $0.53 \mathrm{~mm}$. As carrier gas, He was used at $1.0 \mathrm{ml} \mathrm{min} \mathrm{m}^{-1}$ and temperature programming consisted of an initial temperature of $50^{\circ} \mathrm{C}$ for $2 \mathrm{~min}$, heating at $40^{\circ} \mathrm{C} \mathrm{min}{ }^{-1}$ to $80^{\circ} \mathrm{C}$, holding at $80^{\circ} \mathrm{C}$ for $2 \mathrm{~min}$, heating at $20^{\circ} \mathrm{C} \mathrm{min}^{-1}$ to $130^{\circ} \mathrm{C}$, immediately followed by heating at $4^{\circ} \mathrm{C} \mathrm{min}^{-1}$ to $350^{\circ} \mathrm{C}$ and finally holding at $350^{\circ} \mathrm{C}$ for $10 \mathrm{~min}$. The subsequent MS detection in full scan mode covered an $\mathrm{m} / \mathrm{z}$ of $50-650$ with a cycle time of $0.65 \mathrm{~s}$ and followed electron impact ionization with an ionization energy of $70 \mathrm{eV}$.

Signal interpretation and quantification

Diterpenoids, phytosterols and pentacyclic triterpenoids were identified from the chromatograms by their mass spectra and retention times. To facilitate inter-sample comparison, relative retention times (RRT) of the various compounds to the internal $\mathrm{d}_{41}-n-\mathrm{C}_{20}$ alcohol standard were calculated. The compounds were identified using 
the NIST MS-Spectra Library as well as an MSspectra database provided by Prof. Dr. Whatley of the Department of Plant Sciences, University of Oxford, UK (available upon request). In addition, one triterpenoid $\left(\mathrm{C}_{30}\right.$ triterpenyl acid) was identified based on data from Van Bergen et al. (1997). In spite of the consultation of the two exhaustive MS-spectral libraries just described, we were unable to identify all compounds encountered completely. Specifically, a number of compounds could only generically be identified as phytosterols based on the presence of characteristic fragment ions represented by $m / z=55,69$, $73,95,109,121$ and 135 analogous to the mass spectra of known phytosterols. Such phytosterols that could not be further specified were labeled 'unknown sterol' followed by a number. The abundance of the various mass fragment ions of these 'unknown sterols' are provided in Table 4. In addition, several pentacyclic triterpenoids could not be identified further than being an analogue or isomer of a certain known compound due to very similar mass spectra. The denomina- tor 'isomer' was used for two or more compounds differing in RRT, but having identical mass spectra, while the denominator 'analogue' was used for compounds with mass spectra containing most but not all characteristic mass fragment ions of a known compound. Fortunately, phytosterols or pentacyclic triterpenoids that were not (completely) identified can still serve as potential biomarkers, since they possessed a unique combination of RRT and mass spectrum that allows for unequivocal recognition in plant material as well as records.

Absolute quantification was not attempted, since obtaining standards of all isoprenoids encountered was impossible. Instead, quantification was performed by comparison of the total ion current (TIC) peak areas for each component of interest to the peak areas from the internal $\mathrm{d}_{41}-n$ $\mathrm{C}_{20}$ alcohol standard. This enabled comparison of the concentration ratio of the various components that were identified within a given component class and gave a general idea of the absolute amount present. In our view, this procedure was

Table 4 Characteristic fragment ions $(\mathrm{m} / \mathrm{z})$ of the sterols that could not be further identified

\begin{tabular}{|c|c|}
\hline Name & Characteristic fragment ions $(\mathrm{m} / z)$; relative abundance between brackets \\
\hline Unknown sterol 1 & $\begin{array}{l}55(35), 69(100), 73(52), 95(72), 109(68), 121(54), 135(34), 163(38), 173(20), 259(9), 287(11), 457(5), \\
\quad 485(5)\end{array}$ \\
\hline Unknown sterol 2 & $\begin{array}{l}55(94), 69(80), 73(74), 95(100), 109(82), 121(74), 123(87), 135(54), 147(51), 161(40), 175(38) \\
\quad 189(24), 299(18), 341(11), 381(15), 424(10)\end{array}$ \\
\hline Unknown sterol 3 & $\begin{array}{l}55(31), 69(40), 73(74), 95(85), 109(100), 121(45), 135(38), 159(38), 173(41), 189(55), 205(56), \\
219(44), 229(24), 243(16), 422(16)\end{array}$ \\
\hline Unknown sterol 4 & $\begin{array}{l}55(84), 69(91), 73(63), 95(100), 107(66), 109(61), 121(63), 135(37), 147(42), 161(23), 175(26), \\
\text { 201(19), 313(11), 423(11) }\end{array}$ \\
\hline Unknown sterol 5 & $\begin{array}{l}55(34), 69(48), 73(100), 95(89), 109(66), 121(42), 135(26), 143(39), 156(24), 189(24), 205(34), \\
\quad 218(14), 259(11), 393(10), 429(10), 483(5)\end{array}$ \\
\hline Unknown sterol 6 & $\begin{array}{l}55(36), 69(45), 73(45), 95(100), 107(57), 109(51), 119(41), 121(40), 133(34), 135(28), 147(25), \\
175(36), 187(16), 205(15), 288(10), 297(13), 341(8), 367(10), 395(22), 410(12)\end{array}$ \\
\hline Unknown sterol 7 & $\begin{array}{l}55(50), 69(80), 73(100), 95(74), 107(63), 109(54), 121(43), 135(45), 147(32), 175(25), 187(17), \\
\quad 203(16), 353(8), 379(28), 407(26), 422(16), 523(10)\end{array}$ \\
\hline Unknown sterol 8 & $\begin{array}{l}55(34), 69(66), 73(71), 75(73), 95(100), 109(84), 121(62), 123(54), 135(28), 147(38), 161(20,177(20), \\
\quad 205(15), 237(40), 257(12), 305(8), 347(12), 395(8), 485(8)\end{array}$ \\
\hline Unknown sterol 9 & $\begin{array}{l}55(54), 69(70), 73(67), 95(100), 109(77), 121(53), 125(49), 135(27), 149(21), 165(44), 177(23) \\
\quad 206(15), 231(14), 257(8), 275(16), 413(7)\end{array}$ \\
\hline Unknown sterol 10 & $\begin{array}{l}55(42), 69(74), 73(100), 95(90), 109(74), 121(54), 129(62), 135(40), 137(44), 149(32), 163(30), \\
173(25), 191(23), 241(72), 255(28), 331(22), 393(64), 483(23), 498(18)\end{array}$ \\
\hline Unknown sterol 11 & $\begin{array}{l}55(94), 69(100), 73(55), 95(82), 109(59), 119(52), 121(46), 133(34), 135(18), 159(27), 187(20), \\
245(44), 257(48), 299(22), 325(20), 339(17), 451(47), 466(15)\end{array}$ \\
\hline Unknown sterol 12 & $\begin{array}{l}55(70), 69(100), 73(54), 95(82), 109(59), 121(44), 129(49), 135(37), 147(24), 187(30), 215(16), \\
227(18), 255(10), 283(14), 309(8), 435(70), 525(20), 540(17)\end{array}$ \\
\hline
\end{tabular}

All contained fragment ions indicative for sterols, represented by $m / z=55,69,95,109,121$ and 135 
adequate to achieve the main aim of our study, i.e. to evaluate the potential of individual components for their use as biomarker for specific (groups of) plant species.

\section{Results and discussion}

\section{Diterpenes in the plant samples}

We identified six different diterpenes, present in the leaves and roots of four of the 19 plant species under consideration (Tables 1, 2, Figs. 1,2). Only the PAR species Espeletia pychnophylla and SARF species Gynoxys buxifolia were found to contain more than one diterpene at substantial concentrations (Figs. 1, 2).

The absence of diterpenes from all but a few species is favorable from a biomarker point of view. Nevertheless, only one compound, isopimaric acid A, met all the criteria for being a biomarker in soils and peat by being present exclusively in the leaves of the SARF species Gynoxis buxifolia (Figs. 1, 2). Pallustric acid was also present exclusively in Gynoxys buxifolia, but was found not only in its leaves but in its roots as well, albeit at much lower concentrations. Since Gynoxys buxifolia is not a peat species, while unsuitable for soil records, pallustric acid constitutes a biomarker for peat records.

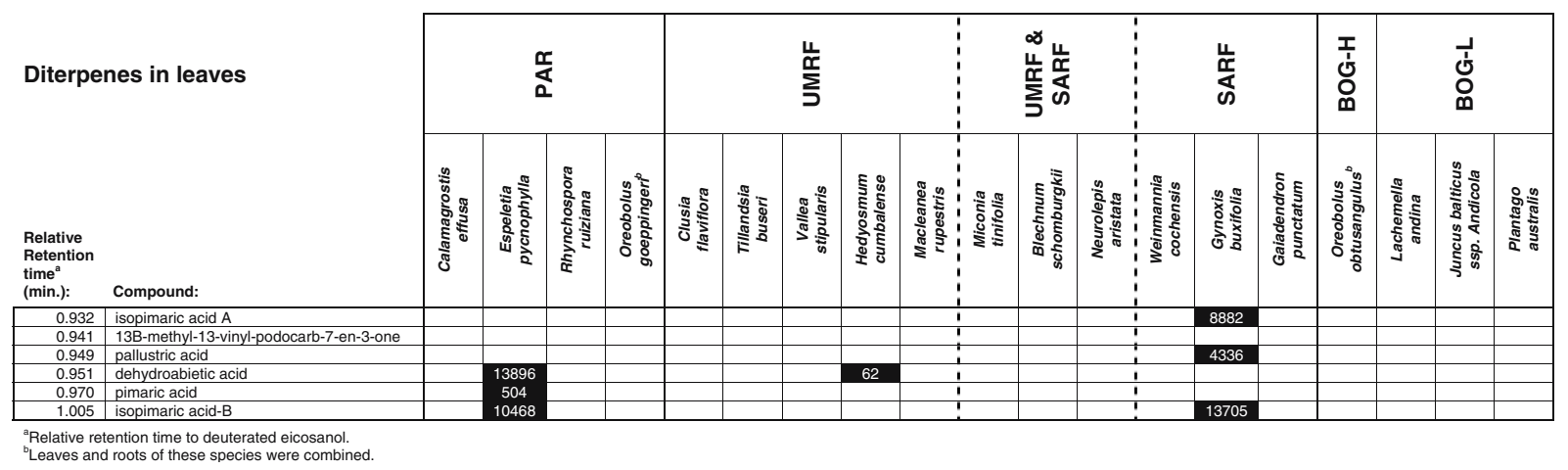

Fig. 1 Distribution of the various diterpenes found in the leaves of the 19 species under study. The number indicates the concentration of the various compounds in $\mu \mathrm{g} \mathrm{g}^{-1}$ of dry plant material, assuming a 1:1 response factor with the deuterated eicosanol internal standard. PAR stands for páramo, UMRF for Upper Montane Rainforest, SARF, for Sub-Alpine Rainforest, BOG-H and BOG-L for, respectively, the peat $\operatorname{bog}(\mathrm{s})$ at higher and lower altitude (see text for further explanation)

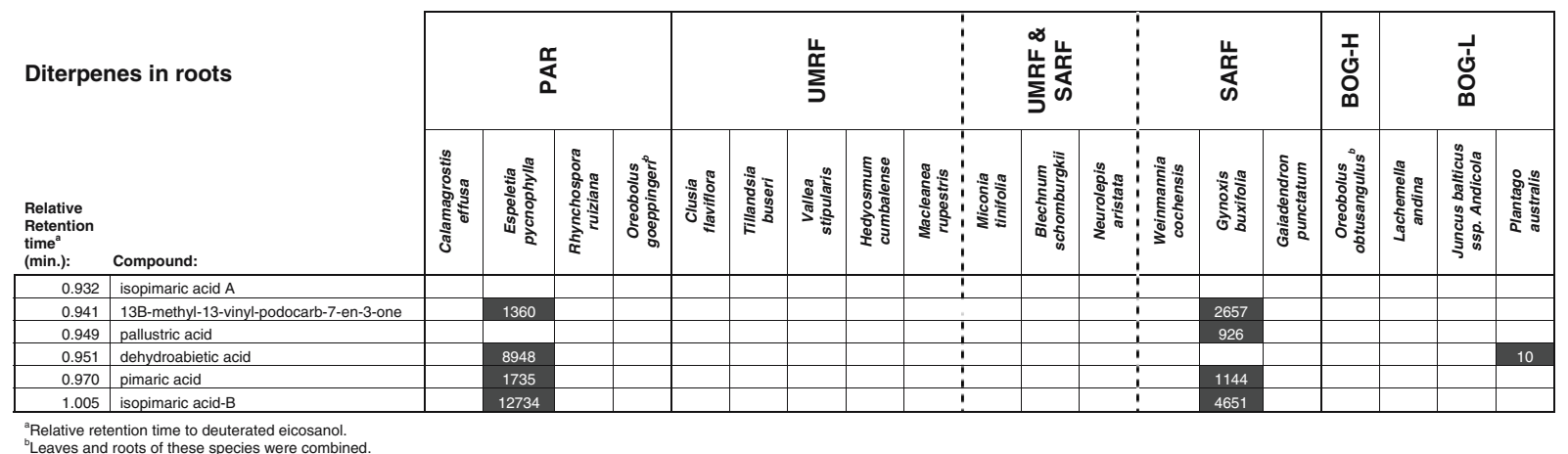

Fig. 2 Distribution of the various diterpenes found in the roots of the 19 species under study. The number indicates the concentration of the various compounds in $\mu \mathrm{g} \mathrm{g}^{-1}$ of dry plant material, assuming a 1:1 response factor with the deuterated eicosanol internal standard. PAR stands for páramo, UMRF for Upper Montane Rainforest, SARF, for Sub-Alpine Rainforest, BOG-H and BOG-L for, respectively, the peat $\operatorname{bog}(\mathrm{s})$ at higher and lower altitude (see text for further explanation) 
Phytosterols in the plant samples

The distribution of phytosterols in the leaves and roots of the plant species under consideration is depicted in Figs. 3 and 4. All leaves and roots of the 19 plant species under investigation contained one or more of the total of 21 phytosterols we encountered (Figs. 3, 4). In addition to several nearly ubiquitos phytosterols, such as $\beta$-sitosterol, a few unique phytosterols were found that thereby constitute potential biomarkers for some of the plant species under study.

Unknown sterol 6 and unknown sterol 12 were present exclusively in the leaves of, respectively, the SARF species Gynoxys buxifolia and the UMRF species Tillandsia sp.2 (Figs. 3, 4) and thereby meet the criteria for biomarker in soils and peat records. In addition, unknown sterol 5 and unknown sterol 8 were exclusively present in the peat species Oreobolus obtusangulus. However, both compounds may have been present in its roots as well since these were not analyzed separately from its leaves as described earlier. In addition, unknown sterol 8 was also present in the roots of Macleanea rupestris. While Oreobolus obtusangulus is a peat species, it is one of the two species of which we do not expect disturbance by non-chronological root input due to their compactness as described previously. In addition, Macleanea rupestris is not a peat species so its roots will not be present in peat records. Consequently, while disqualified for use as biomarker in soils, unknown sterol 5 and unknown sterol 8 meet the criteria for biomarker in peat records for Oreobolus obtusangulus. All other phytosterols appeared to be too generic to serve as biomarkers for our plants.

Pentacyclic triterpenoids in the plant samples

Figures 5 and 6 show the distribution of the pentacyclic triterpenoids we found in the plant species under study organized by terpenoid class, i.e. friedelanes, oleanes plus analogues and ursanes plus analogues. The total of 23 pentacyclic triterpenoids found were encountered in only a few of the 19 plant species under consideration (Figs. 5, 6). Especially the UMRF species Mac-

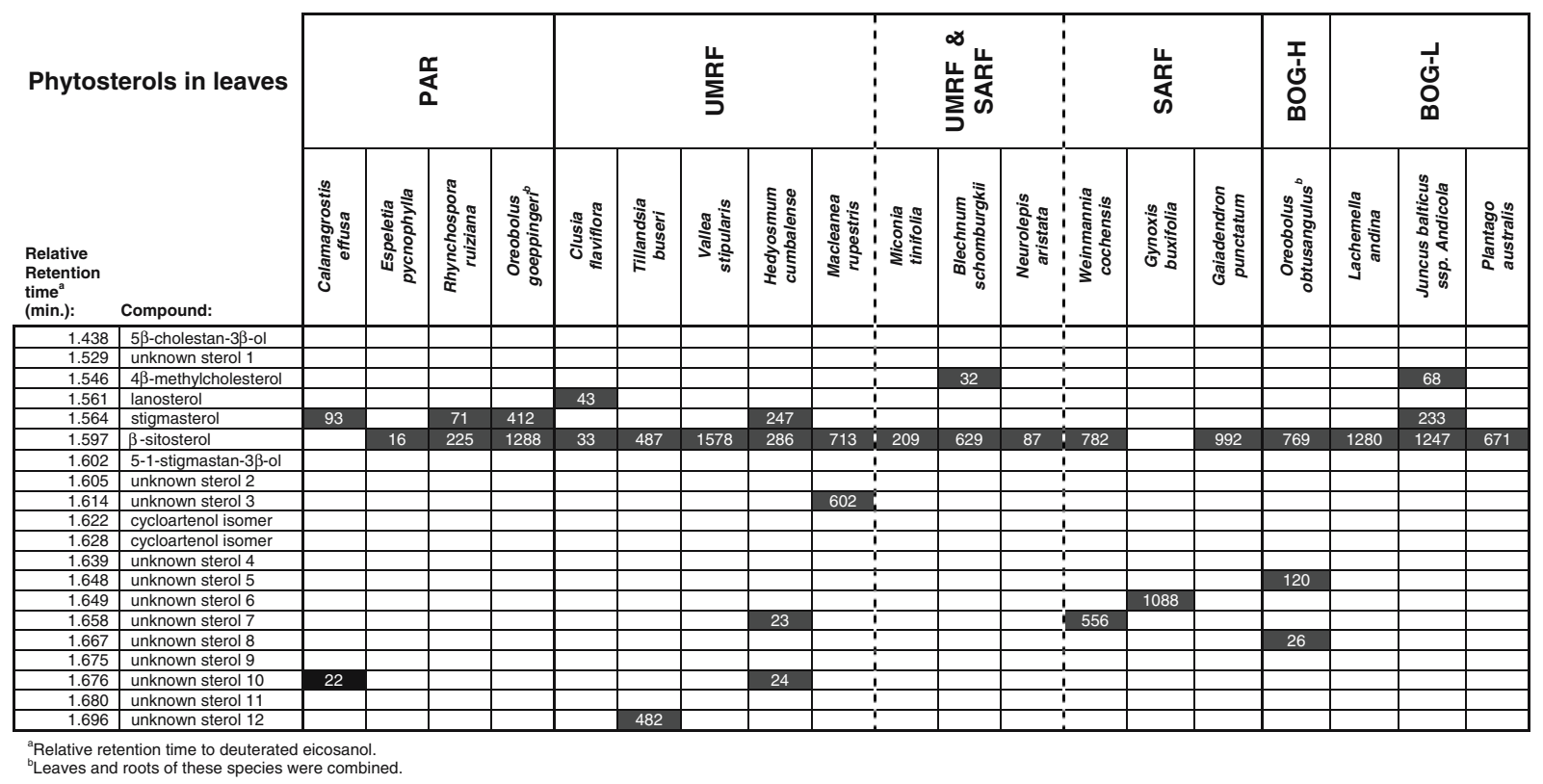

Fig. 3 Distribution of the various phytosterols found in the leaves of the 19 species under study. The number indicates the concentration of the various compounds in $\mu \mathrm{g} \mathrm{g}^{-1}$ of dry plant material, assuming a 1:1 response factor with the deuterated eicosanol internal standard. PAR stands for páramo, UMRF for Upper Montane Rainforest, SARF, for Sub-Alpine Rainforest, BOG-H and BOG-L for, respectively, the peat $\operatorname{bog}(\mathrm{s})$ at higher and lower altitude (see text for further explanation) 


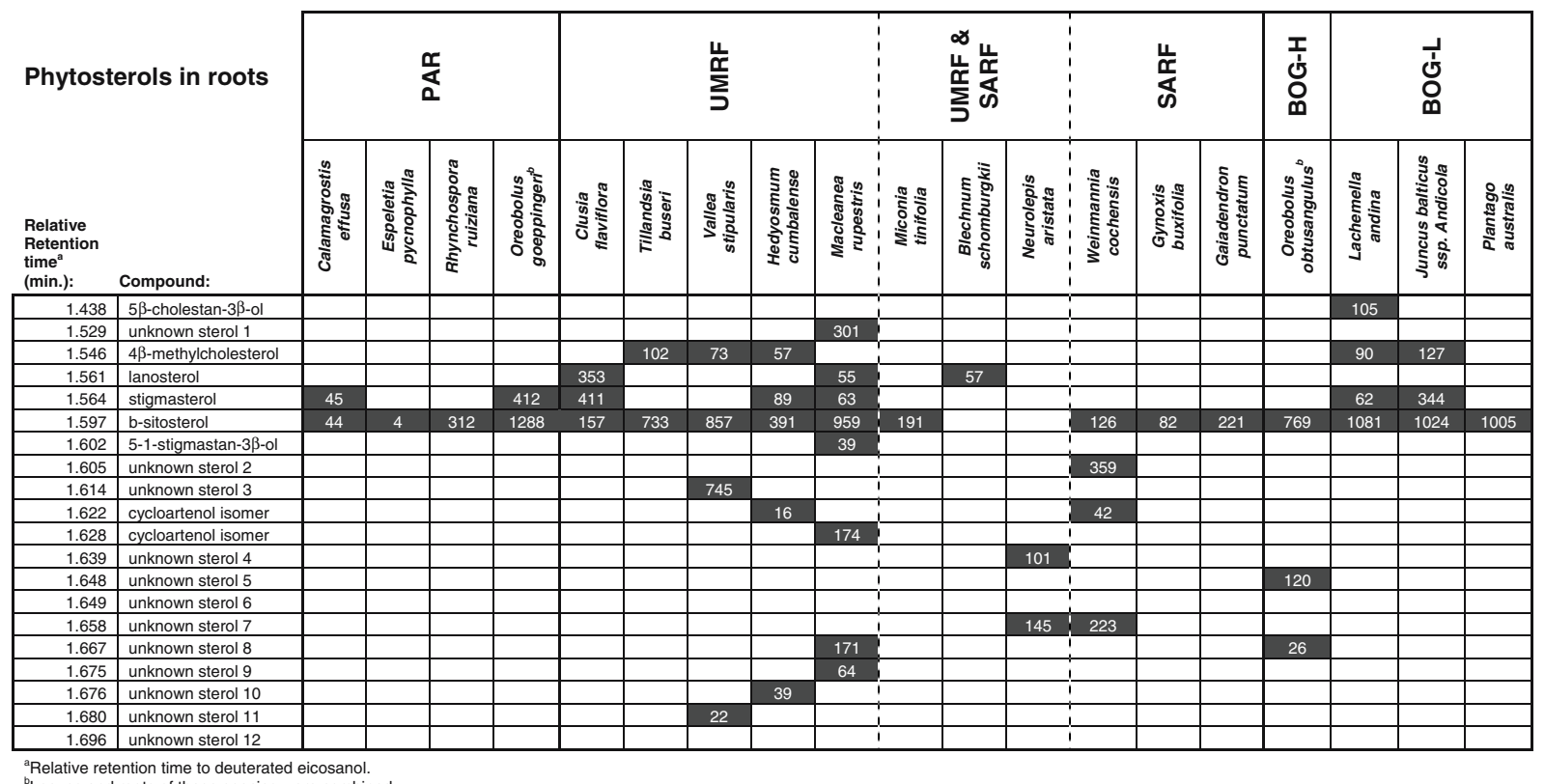

b Leaves and roots of these species were combined.

Fig. 4 Distribution of the various phytosterols found in the roots of the 19 species under study. The number indicates the concentration of the various compounds in $\mu \mathrm{g} \mathrm{g} \mathrm{g}^{-1}$ of dry plant material, assuming a 1:1 response factor with the deuterated eicosanol internal standard. PAR stands for páramo, UMRF for Upper Montane Rainforest, SARF, for Sub-Alpine Rainforest, BOG-H and BOG-L for, respectively, the peat $\operatorname{bog}(\mathrm{s})$ at higher and lower altitude (see text for further explanation)

\section{Pentacyclic triterpenes in leaves}

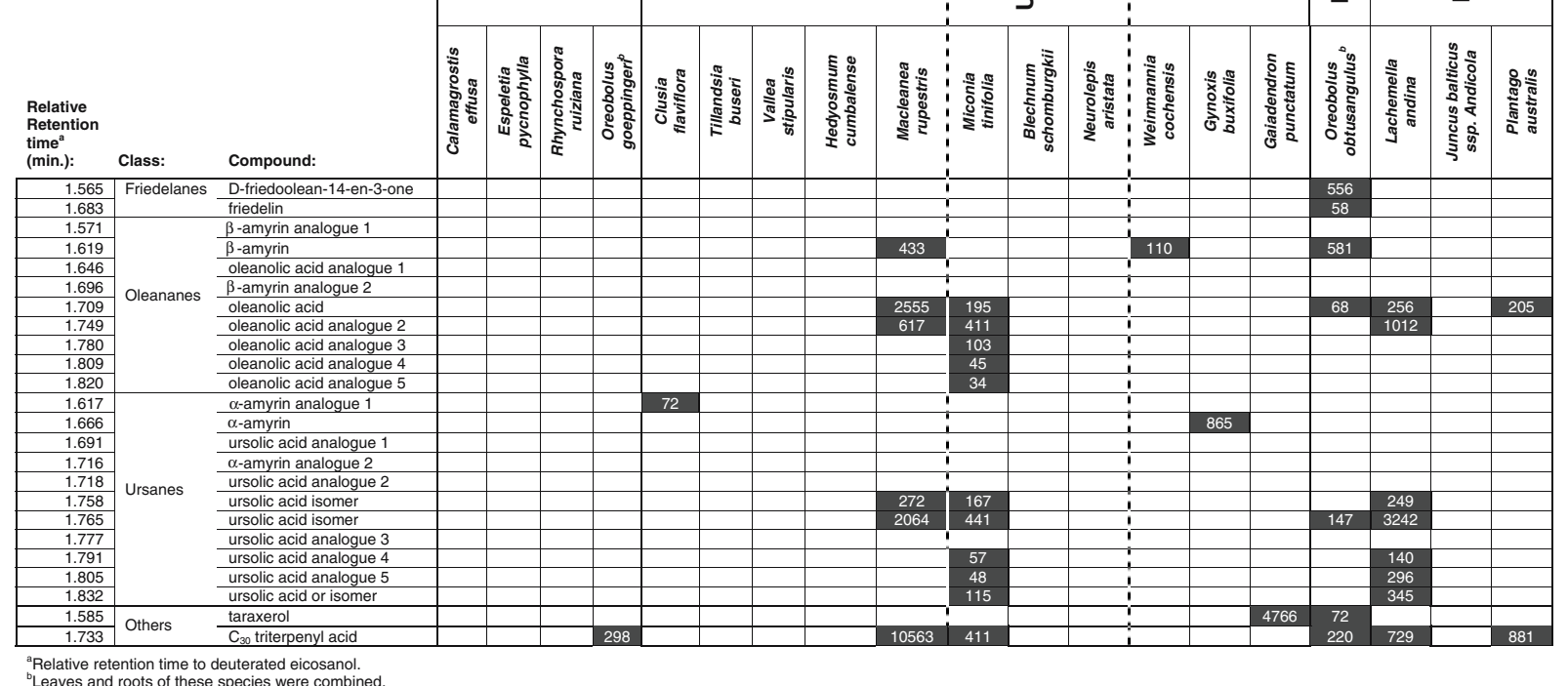

Fig. 5 Distribution of the various pentacyclic triterpenoids found in the leaves of the 19 species under study. The number indicates the concentration of the various compounds in $\mu \mathrm{g} \mathrm{g}^{-1}$ of dry plant material, assuming a 1:1 response factor with the deuterated eicosanol internal standard. PAR stands for páramo, UMRF for Upper Montane Rainforest, SARF, for Sub-Alpine Rainforest, BOG-H and BOG-L for, respectively, the peat bog(s) at higher and lower altitude (see text for further explanation) 


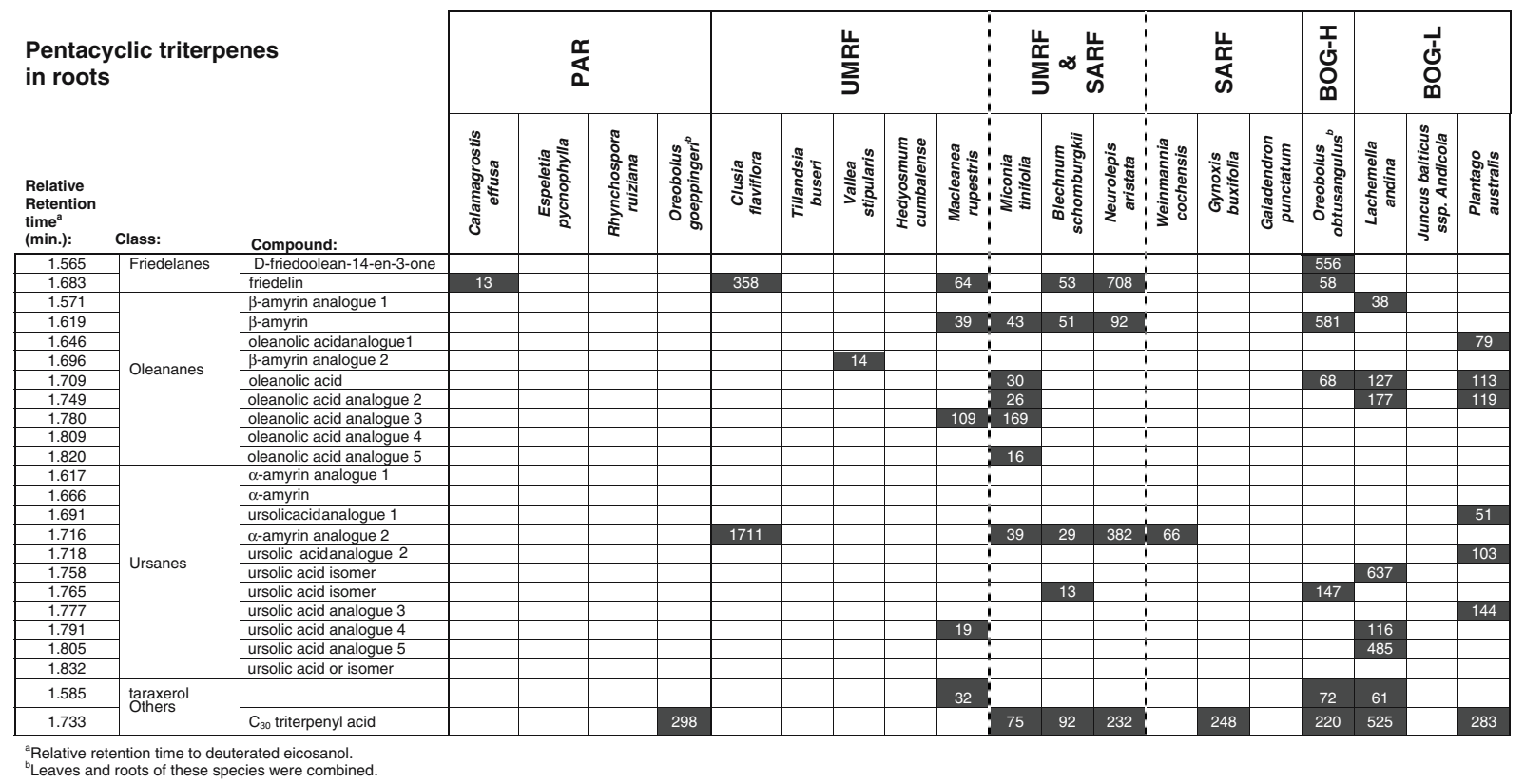

Fig. 6 Distribution of the various pentacyclic triterpenoids found in the roots of the 19 species under study. The number indicates the concentration of the various compounds in $\mu \mathrm{g} \mathrm{g}^{-1}$ of dry plant material, assuming a $1: 1$ response factor with the deuterated eicosanol internal

leanea rupestris, Miconia tinifolia (present in the UMRF and SARF) and the peat-bog species Lachemella andina contained a multitude of pentacyclic triterpenoids in their leaves as well as in their roots. At the same time no pentacyclic triterpenoids at all were identified in leaves or roots of the PAR species Rhynchospora ruiziana and Espeletia pycnophylla, the UMRF species Tillandsia sp. 2 and Hedyosmum cumbalense, the SARF species Gaiadendron punctatum, and the peat bog species Juncus Balticus ssp. andicola (Figs. 5, 6).

Pentacyclic triterpenoids constituting biomarkers in soil and peat records were $\alpha$-amyrin, $\alpha$-amyrin analogue 2 , and oleanolic acid analogue 4 , as they were encountered exclusively in, respectively, the leaves of the SARF species Gynoxys buxifolia, the UMRF species Clusia flaviflora, and Miconia tinifolia (present in the UMRF and SARF) (Figs. 5, 6). Oleanolic acid analogue 5 was also exclusively present in Miconia tinifolia, but was found in its roots as well as its leaves. The same was true for friedelin and standard. PAR stands for páramo, UMRF for Upper Montane Rainforest, SARF, for Sub-Alpine Rainforest, BOG-H and BOG-L for, respectively, the peat bog(s) at higher and lower altitude (see text for further explanation)

D-friedoolean-14-en-3-one that were exclusive to the peat species Oreobolus obtusangulus but may have been present in its roots as well. Miconia tinifolia is not a peat species, while no disturbance by non-chronological root input of Oreobolus obtusangulus in peat records is expected as explained earlier. Consequently, Oleanolic acid analogue 5 meets the criteria of biomarker for Miconia tinifolia in peat records, while friedelin and D-friedoolean-14-en-3-one meet the criteria for biomarker of Oreobolus obtusangulus in peat records.

Preservation of the isoprenoids in the soil and peat samples

In Tables 5, 6 and 7 we presented the isoprenoids encountered in, respectively, the soil samples from the forest patch, the soil samples from the páramo next to it, and the samples from the peat deposit (see Table 3). In addition, the concentration of the encountered compounds in $\mu \mathrm{g}$ per $\mathrm{g}$ of absolute dry soil or peat material as well as their 
Table 5 Isoprenoids identified in two soil samples at different depth and age from a forest patch in the Guandera study site linked to their occurrence in present-day plant species from the various relevant biotopes (see text for further explanation)

a The number of $\mathrm{x}$-es indicates the number of species from a specific biotope in which the compound was present b Approximate age based on ${ }^{14} \mathrm{C}$ dating, see Table 3

\begin{tabular}{|c|c|c|c|c|c|}
\hline & \multirow{2}{*}{$\begin{array}{l}\mu \mathrm{g} \mathrm{g}^{-1} \text { dry } \\
\text { material }\end{array}$} & \multicolumn{4}{|c|}{ Present in species from ${ }^{\mathrm{a}}$} \\
\hline & & Paramo & UMRF & UMRF\&SARF & SARF \\
\hline \multicolumn{6}{|c|}{ Sample from forest patch at approx. $1500 \mathrm{cal} A D^{b}$} \\
\hline$\beta$-Sitosterol & 24 & \multicolumn{4}{|c|}{ Ubiquitous } \\
\hline Unknown sterol 2 & 78 & - & - & - & $\mathrm{X}$ \\
\hline$\beta$-Amyrin & 2.4 & $\mathrm{x}$ & $\mathrm{x}$ & $\mathrm{xxx}$ & $\mathrm{x}$ \\
\hline Cycloartenol & 4.8 & - & $\mathrm{x}$ & - & $\mathrm{x}$ \\
\hline Unknown sterol 7 & 2.5 & - & $\mathrm{x}$ & $\mathrm{x}$ & $\mathrm{x}$ \\
\hline Unknown sterol 8 & 1.6 & $\mathrm{x}$ & $\mathrm{x}$ & - & - \\
\hline Friedelin & 1.1 & $\mathrm{xx}$ & $\mathrm{xx}$ & $\mathrm{xx}$ & - \\
\hline Oleanolic acid & 3.0 & $\mathrm{x}$ & $\mathrm{x}$ & $\mathrm{x}$ & - \\
\hline$\alpha$-Amyrin analogue 2 & 6.2 & - & $\mathrm{x}$ & $\mathrm{xxx}$ & $\mathrm{x}$ \\
\hline $\mathrm{C}_{30}$ triterpenyl acid & 25 & $\mathrm{x}$ & $\mathrm{x}$ & $\mathrm{xxx}$ & $\mathrm{x}$ \\
\hline \multicolumn{6}{|c|}{ Sample from forest patch at approx. $200 \mathrm{cal} A D^{b}$} \\
\hline$\beta$-Sitosterol & 7.1 & \multicolumn{4}{|c|}{ Ubiquitous } \\
\hline$\beta$-Amyrin & 5.3 & $\mathrm{x}$ & $\mathrm{x}$ & $\mathrm{xxx}$ & $\mathrm{x}$ \\
\hline Unknown sterol 8 & 2.1 & $\mathrm{x}$ & $\mathrm{x}$ & - & - \\
\hline Friedelin & 0.6 & $\mathrm{xx}$ & $\mathrm{xx}$ & $\mathrm{xx}$ & - \\
\hline Oleanolic acid & 5.2 & $\mathrm{x}$ & $\mathrm{x}$ & $\mathrm{x}$ & - \\
\hline$\alpha$-Amyrin analogue 2 & 0.9 & - & $\mathrm{x}$ & $\mathrm{xxx}$ & $\mathrm{x}$ \\
\hline $\mathrm{C}_{30}$ triterpenyl acid & 50 & $\mathrm{x}$ & $\mathrm{x}$ & $\mathrm{xxx}$ & $\mathrm{x}$ \\
\hline
\end{tabular}

Table 6 Isoprenoids identified in two soil samples at different depth and age from the páramo adjacent to the forest patch in the Guandera study site linked to their occurrence in present-day plant species from the various relevant biotopes (see text for further explanation)

$\mu \mathrm{g} \mathrm{g}^{-1}$ dry material Present in species from ${ }^{\mathrm{a}}$

\begin{tabular}{llll}
\hline Paramo UMRF & UMRF\&SARF & SARF
\end{tabular}

Sample from páramo next to forest patch at approx. $1350 \mathrm{cal} A D^{b}$

$\beta$-Sitosterol $\quad 1.0$

Oleanolic acid $\quad 0.4$

$\mathrm{C}_{30}$ triterpenyl acid $\quad 5.4$

Ubiquitous

Sample from páramo next to forest patch at approx. $200 \mathrm{cal} \mathrm{BC^{b }}$

$\begin{array}{llllll}\beta \text {-Sitosterol } & 3.3 & \text { Ubiquitous } & & & \\ \text { Unknown sterol } 7 & 0.5 & - & \mathrm{x} & \mathrm{x} & \\ \text { Oleanolic acid } & 2.8 & \mathrm{x} & \mathrm{x} & \mathrm{x} & \\ \mathrm{C}_{30} \text { triterpenyl acid } & 6.7 & \mathrm{x} & \mathrm{x} & \mathrm{xxx} & \mathrm{x}\end{array}$

a The number of $\mathrm{x}$-es indicates the number of species from a specific biotope in which the compound was present

b Approximate age based on ${ }^{14} \mathrm{C}$ dating, see Table 3

distribution over present-day species from the different vegetation clusters relevant for an UFL reconstruction are provided (Tables 5-7).

From Tables 5-7 a marked difference in the number of components encountered and their relative concentrations can be discerned between the type of record (soil under forest, soil under páramo and peat bog), as well as between the younger and the older samples. Isoprenoids of all classes were abundantly present in the presentday vegetation in all vegetation groups (Figs. 1-6).
Therefore, differences in abundance and concentration in the soil and peat records can be due to a difference in biomass input, a difference in preservation, or a combination of both.

The younger sample from the peat bog clearly contained the highest number of isoprenoids (12) and at the highest concentrations. The younger soil sample under forest contained almost as many different components (10) as the peat sample, but at much lower concentrations, while the younger soil sample under páramo contained only few 
Table 7 Isoprenoids identified in two soil samples at different depth and age from the peat deposit in the Guandera site linked to their occurrence in present-day plant species from the various relevant biotopes (see text for further explanation)

a The number of $\mathrm{x}$-es indicates the number of species from a specific biotope in which the compound was present

b Approximate age based on ${ }^{14} \mathrm{C}$ dating, see Table 3

\begin{tabular}{|c|c|c|c|c|c|c|}
\hline & \multirow{2}{*}{$\begin{array}{l}\mu \mathrm{g} \mathrm{g}^{-1} \text { dry } \\
\text { material }\end{array}$} & \multicolumn{5}{|c|}{ Present in species from ${ }^{a}$} \\
\hline & & Paramo & UMRF & UMRF\&SARF & SARF & $\mathrm{BOG}$ \\
\hline \multicolumn{7}{|c|}{ Sample from peat deposit $1550 \mathrm{cal} A D^{b}$} \\
\hline D-friedolean-14-en-3-one & 136 & $\mathrm{x}$ & - & - & - & - \\
\hline Taraxerol & 110 & $\mathrm{x}$ & - & - & $\mathrm{x}$ & - \\
\hline$\beta$-Sitosterol & 333 & \multicolumn{5}{|c|}{ Ubiquitous } \\
\hline$\beta$-Amyrin & 73 & $\mathrm{x}$ & $\mathrm{x}$ & - & $\mathrm{x}$ & - \\
\hline Unknown sterol 5 & 28 & $\mathrm{x}$ & - & - & - & - \\
\hline Unknown sterol 7 & 24 & - & $\mathrm{x}$ & - & $\mathrm{x}$ & - \\
\hline Unknown sterol 8 & 240 & $\mathrm{x}$ & - & - & - & - \\
\hline Unknown sterol 10 & 120 & $\mathrm{x}$ & $\mathrm{x}$ & - & - & - \\
\hline Friedelin & 86 & $\mathrm{x}$ & - & - & - & - \\
\hline Oleanolic acid & 348 & $\mathrm{x}$ & $\mathrm{x}$ & $\mathrm{x}$ & - & $\mathrm{xx}$ \\
\hline $\mathrm{C}_{30}$ triterpenyl acid & 115 & $\mathrm{x}$ & $\mathrm{x}$ & $\mathrm{x}$ & - & $\mathrm{xxx}$ \\
\hline Oleanolic acid derivative 5 & 406 & - & - & $\mathrm{x}$ & - & - \\
\hline \multicolumn{7}{|c|}{ Sample from peat deposit $150 \mathrm{cal} \mathrm{BC^{b }}$} \\
\hline Pallustric acid & 1.4 & - & - & - & $\mathrm{x}$ & - \\
\hline$\beta$-Sitosterol & 6.0 & \multicolumn{5}{|c|}{ Ubiquitous } \\
\hline$\beta$-Amyrin & 2.5 & $\mathrm{x}$ & $\mathrm{x}$ & - & $\mathrm{x}$ & - \\
\hline $\mathrm{C}_{30}$ triterpenyl acid & 13 & $\mathrm{x}$ & $\mathrm{x}$ & $\mathrm{x}$ & & $\mathrm{xxx}$ \\
\hline
\end{tabular}

When looking at the older samples studied,
there was a slight decline in abundance and isoprenoids (3) and at even lower concentrations (Tables 5-7). Because of their acidic and anaerobic environment, organic matter is generally very well preserved in peat records. Therefore, the much higher concentrations of isoprenoids in the younger peat sample were most likely caused by better preservation than in the soils. General soil chemical and moisture conditions are similar in the soil under forest and under páramo (Tonneijck et al. 2006). Consequently, one would not expect differences in preservation of the isoprenoids to be the cause for the observed smaller number and concentrations of isoprenoids found in the younger páramo soil as compared to the younger forest soil. On the other hand, if certain classes of isoprenoids degrade more easily than others, differences in degradation under similar general soil conditions may still take place. In this respect it is interesting to note that none of the diterpenoids that were present in large concentrations in various páramo plants (Figs. 1,2) were found even in the younger sample under páramo. Possibly this class of isoprenoids is more susceptible to degradation under the general soil conditions in our study area than the dominant isoprenoids from forest vegetation. Another explanation is that differences in above ground biomass input were the cause of the differences observed between the younger forest and páramo soils. concentration of isoprenoids going from the younger to the older forest soil sample (Table 5). In contrast, in the older peat sample the number of isoprenoids and their concentrations were much lower than in the younger peat sample (Table 7). The latter result is somewhat surprising in light of the expected better preservation of isoprenoids in peat deposits than in soils. However, the most surprising observation was that in the older soil sample under páramo one more compound was encountered than in the younger one, and general concentrations of the compounds were slightly larger than in the younger sample (Table 6). It is hard to explain such an inverse relationship of concentration and abundance of isoprenoids with depth within one and the same soil horizon in terms other than a difference in input of isoprenoids at the time of deposition of the older páramo sample, indicating a different vegetation composition at that time. This is an important observation because it implies that a sudden increase in number and concentration of isoprenoids with depth within the same soil horizon might be used as an additional indicator of past changes in vegetation composition. However, it is clear that further study is needed to pin-point the exact mechanism 
of preservation of isoprenoids in soil and peat records.

The present study shows that the difference in concentration and number of isoprenoids encountered in the soil and peat samples tested are much lower than in the leaves and roots of the plant species under consideration. At the same time the previous study of straight-chain lipids showed that the difference in concentration and number of relevant straight-chain lipids, i.e. $n$-alcohols and $n$-alkanes, in the soil and peat samples as compared to the leaves and roots of the plants was very small (Jansen et al. 2006a). This leads to the conclusion that $n$-alcohols and $n$-alkanes are better preserved in the peat deposits as well as the soils in the study area than the isoprenoid classes tested in the present study. This observation is in agreement with the results of a previous study of soils under pine vegetation (Nierop et al. 2005).

Interpretation of the isoprenoid signal from the soil and peat samples

The set of samples that were extracted was too limited to attempt an UFL reconstruction of the study area, nor was that the purpose of this study. Still we were able to use the data for a preliminary assessment of the value of isoprenoid-biomarkers as proxy for UFL reconstructions in the area.

When looking at the soil samples, we did not encounter any biomarkers. All but one of the isoprenoids found occurred in species from more than one biotope. Only in the younger soil sample from the forest patch did we find a compound unique for a single species (unknown sterol 2, for Weinmannia cochensis, see Table 5), however this compound occurs in its leaves as well as in its roots and therefore does not qualify as biomarker in soils (Figs. 3, 4). Nevertheless, useful information might be gained not from the compounds themselves but from the vast difference in number and concentration of isoprenoids found between the soil samples from under forest versus under páramo vegetation (Tables 5-7). As explained earlier the increase in number of compounds and their concentrations in the older páramo sample as compared to the younger one from the same soil horizon could be interpreted as an indication of a historic shift in vegetation composition. While in this particular case the observed difference on its own might not be pronounced enough to serve as an exclusive indicator of a historic forest vegetation, it is certainly a useful indicator to be used in conjunction with other proxies such as straight-chain lipids or isoprenoid biomarkers from other records such as peat deposits.

Contrary to the soil samples studied, the isoprenoids encountered in the peat deposits appear to provide more useful information for an UFL reconstruction (Table 7). In the younger sample as many as three compounds classified as biomarkers were found, all of them indicative of the same peat species: Oreobolus obtusangulus (Figs. 3, 5). In the older sample, we encountered one biomarker, this time for a SARF species: Gynoxis buxifolia. Analogous to pollen, the biomarkers most likely entered the peat bog in the form of wind-blown leaf material, albeit originating from much closer by than pollen would. A SARF signal in the older sample is consistent with the expected depression of the UFL in the study area due to human interference over the last centuries. It is also in agreement with the observation that the increase in abundance and concentration of isoprenoids in the older páramo sample signifies a difference in historic vegetation composition. Better preservation of isoprenoids in the top part and the absence of root input from all but the peat species themselves, together result in a higher potential of peat deposit from an isoprenoid biomarker point of view than soil records in the study area.

\section{Conclusions}

Altogether, we found five isoprenoids that meet our criteria for biomarker in both soils and peat records. Two of these represent UMRF species (Tillandsia sp. 2 and Clusia flaviflora), two represent the same SARF species (Gynoxys buxifolia) and one represents a species present in both UMRF and SARF (Miconia tinifolia). In addition, we encountered six isoprenoids that may serve as biomarkers in peat records but due to their (possible) presence in roots are not applica- 
ble to soils. One is representative for Gynoxys buxifolia, another for Miconia tinifolia and four represent the peat bog species Oreobolus obtusangulus. Because input of roots from species other than the peat bog species themselves can be ruled out in the peat deposit studied and isoprenoids appear to be better preserved at least in the top part of the deposit, such deposits appear to be the most valuable records of isoprenoid biomarkers in our study area. In addition, changes of the number and concentration of isoprenoids within one soil horizon as was observed, might provide additional information about past vegetation changes. While one can debate whether historic vegetation can be reconstructed based upon isoprenoids alone, we conclude that isoprenoid biomarkers certainly have potential to serve as a supporting proxy in a multi-proxy approach for reconstructing past vegetation in our study area in the Northern Ecuadorian Andes, and other ecosystems with similar vegetation and soils.

Acknowledgements We would like to thank the fellow members of the RUFLE program: Henry Hooghiemstra, Antoine Cleef and Marcela Moscol for their input and help. In this respect we also thank our Ecuadorian partners at EcoPar, Randi-Randi and the Pontificia Universidad Católica del Ecuado, as well as the Ministerio del Ambiente de la República del Ecuador. Furthermore, we are grateful to the Jatun Sacha volunteers Chris James, Lewis Whale, Lyndsay Gray and Andy Pester for their invaluable help during the fieldwork. We are greatly indebted to Prof. Dr. Bob Whatley for allowing us access to his extensive MS database. This study would not have been possible without his help. We are also grateful to Pim de Voogt for his suggestions. The Netherlands Foundation for the Advancement of Tropical Research (NWOWOTRO) is gratefully acknowledged for their funding of the RUFLE program in general as well as this individual project (WAN 75-406). We thank Fjällräven for their generous sponsoring in the form of clothing and gear.

\section{References}

Brush SB (1982) The natural and human environment of the central Andes. Mountain Res Develop 2:19-38

Bull ID, Nott CJ, van Bergen PF, Poulton PR, Evershed RP (2000a) Organic geochemical studies of soils from the Rothamsted classical experiments-VI. The occurrence and source of organic acids in an experimental grassland soil. Soil Biol Biochem 32:13671376
Bull ID, van Bergen PF, Nott CJ, Poulton PR, Evershed RP (2000b) Organic geochemical studies of soils from the Rothamsted classical experiments-V. The fate of lipids in different long-term experiments. Org Geochem 31:389-408

Chaffee AL, Hoover DS, Johns RB, Schweighardt FK (1986) Biological markers extractable from coal. In: Johns RB (eds) Biological markers in the sedimentary record. Elsevier, Amsterdam, pp 311-345

De Leeuw JW, Baas M (1986) Early-stage diagenesis of steroids. In: Johns RB (eds) Biological markers in the sedimentary record. Elsevier, Amsterdam, pp 101-123

Dinel H, Schnitzer M, Meyhus GR (1990) Soil lipids: origin, nature, content, decomposition, and effect on soil physical properties. In: Bollag JM, Stotzky G (eds) Soil biochemistry. Marcel Dekker Inc., New York, pp 397-429

Dodson CH, Gentry AH (1991) Biological extinction in Western Ecuador. Ann Missouri Bot Garden 78:273295

FAO (2006) World reference base for soil resources 2006. FAO, Rome, Italy

Jaffe R, Elisme T, Cabrera AC (1996) Organic geochemistry of seasonally flooded rain forest soils: molecular composition and early diagenesis of lipid components. Org Geochem 25:9-17

Jansen B, Nierop KGJ, Hageman JA, Cleef A, Verstraten JM (2006a) The straight-chain lipid biomarker composition of plant species responsible for the dominant biomass production along two altitudinal transects in the Ecuadorian Andes. Org Geochem 37:1514-1536

Jansen B, Nierop KGJ, Kotte MC, De Voogt P, Verstraten JM (2006b) The application of accelerated solvent extraction (ASE) to extract lipid biomarkers from soils. Appl Geochem 21:1006-1015

Killops SD, Frewin NL (1994) Triterpenoid diagenesis and cuticular preservation. Org Geochem 21:1193-1209

Laegaard S (1992) Influence of fire in the grass páramo vegetation of ecuador. In: Balslev H, Luteyn JL (eds) Páramo, an andean ecosystem under human influence. Academic Press, London, pp 151-170

Moore PD, Webb JA, Collinson ME (1991) Pollen Analysis, 2nd edn. Blackwell Scientific Publishing, Oxford, 207p

Myers N (1988) Threatened biotas: "hot-spots" in tropical forests. Environmentalist 8:187-208

Naafs DFW, van Bergen PF, Boogert SJ, de Leeuw JW (2004) Solvent-extractable lipids in an acid andic forest soil; variations with depth and season. Soil Biol Biochem 36:297-308

Nierop KGJ, Verstraten JM (2004) Rapid molecular assessment of the bioturbation extent in sandy soil horizons under, pine using ester-bound lipids by online thermally assisted hydrolysis and methylation-gas chromatography/mass spectrometry. Rapid Commun Mass Spectrom 18:1081-1088

Nierop KGJ, Van Bergen PF, Buurman P, Van Lagen B (2005) $\mathrm{NaOH}$ and $\mathrm{Na}_{4} \mathrm{P}_{2} \mathrm{O}_{7}$ extractable organic matter in two allophanic volcanic ash soils of the azores islands-a pyrolysis GC/MS study. Geoderma 127:3651 
Ohsaki A, Shibata K, Kubota T, Tokoroyama T (1999) Phylogenetic and chemotaxonomic significance of diterpenes in some Portulaca species (portulacaceae). Biochem Syst Ecol 27:289-296

Otto A, Shunthirasingham C, Simpson MJ (2005) A comparison of plant and microbial biomarkers in grassland soils from the prairie ecozone of Canada. Org Geochem 36:425-448

Otto A, Simpson MJ (2005) Degradation and preservation of vascular plant-derived biomarkers in grassland and forest soils from Western Canada. Biogeochemistry 74:377-409

Ramsay PM, Oxley ERB (2001) An assessment of aboveground net primary productivity in andean grasslands of Central Ecuador. Mountain Res Develop 21:161167

Salomons JB (1986) Paleoecology of volcanic soils in the Colombian Central Cordillera (Parque Nacional Natural de los Nevadas). Disertaciones Botanicae 95. J. Cramer, Berlin, 212p

Shoji S, Nanzyo M, Dahlgren RA (1993) Volcanic ash soils genesis, properties and utilization. Elsevier, Amsterdam, The Netherlands
Simoneit BRT (1986) Cyclic terpenoids of the geosphere. In: Johns RB (ed) Biological markers in the sedimentary record. Elsevier, Amsterdam, pp 43-99

Stevenson FJ (1994) Humus chemistry: genesis, composition, reactions. John Wiley \& Sons, Inc., New York

Tonneijck FH, Van der Plicht J, Jansen B, Verstraten JM, Hooghiemstra H (2006) Radiocarbon dating of soil organic matter fractions in Andosols in Northern Ecuador. Radiocarbon 48:337-353

Van Bergen PF, Bull ID, Poulton PR, Evershed RP (1997) Organic geochemical studies of soils from the Rothamsted classical experiments-I. Total lipid extracts, solvent insoluble residues and humic acids from Broadbalk Wilderness. Org Geochem 26:117135

Volkman JK (2005) Sterols and other triterpenoids: source specificity and evolution of biosynthetic pathways. Org Geochem 36:139-159

Wille M, Hooghiemstra H, Hofstede R, Fehse J, Sevink J (2002) Upper forest line reconstruction in a deforested area in Northern Ecuador based on pollen and vegetation analysis. J Trop Ecol 18:409-440 